\title{
Entrepreneurship in the Digital and Industry 4.0 Age: A semi-systematic literature review
}

\author{
Isabelle BICLESANU \\ Bucharest University of Economic Studies, Bucharest, Romania \\ isabelle.bn@pm.me \\ Alina DIMA \\ Bucharest University of Economic Studies, Bucharest, Romania \\ alina.dima@ase.ro
}

\begin{abstract}
Industry 4.0 and digitalization are changing the business world. While companies are optimizing their processes and adapting to the new market conditions, some entrepreneurs are pushing the boundaries by creating new organizations that are capitalizing on the digital environment or even building the technologies behind it, achieving fast, impressive results. The paper is concerned with characterizing the Romanian entrepreneurship within the digitalization and Industry 4.0 context, through the means of a semisystematic literature review of articles and conference proceedings published within last five years, indexed in the Thomson Reuters Web of Science (WoS) Core Collection database. Manual filtering, categorization and synthesis of the relevant articles were used along with co-occurrence networks built in VOSviewer. The main directions were discovered to be in six areas on the use of technology in business and two areas which were also particularly related to entrepreneurship education.
\end{abstract}

Keywords: Entrepreneur, Digital, Digitization, Industry 4.0, Automation, Management, Literature review.

\section{Introduction}

Industry 4.0 and digitalization can work as enablers of improved business processes, all the way to becoming a functional part of the organization, having high impact over strategic decision making (Bleicher \& Stanley, 2018), and the way in which companies achieve and sustain competitive advantage (Lanzolla \& Frankort, 2016). Moreover, innovation in high tech companies has positive outcomes for society, especially in the healthcare, infrastructure and environmental protection areas (Grigorescu et al., 2020).

Some entrepreneurs are recognizing the opportunities in using digital technologies by creating new companies that are capitalizing on the digital environment or even building the technologies behind it, achieving fast, impressive results, such as Druid AI, a Romanian chatbot authoring platform (Anagnoste et al., 2021), or UiPath, a Romanian company and the leading robotic process automation (RPA) provider worldwide (Forrester Research, 2019). Moreover, only in 2020, the biggest angel investor network in Romania invested around EUR 4mil in 75 startups providing tech-based solutions (Chiriseala, 2021).

However, Romania lacks a national digital transformation strategy aimed at supporting the digitalization of enterprises and at raising awareness regarding digital technologies' benefits (European Commission, 2020).

The paper is aiming to characterize the Romanian companies within the Industry 4.0 and digitalization context through the means of a semi-systematic literature review of articles and conference proceedings published within last five years, as technology is rapidly changing and the 
phrase the Fourth Industrial Revolution was introduced to a wider audience in 2015 (Schwab, 2015), and again in 2016 by the World Economic Forum (Schwab, 2016).

\section{Methodology}

The Core Collection database of the Thomson Reuters Web of Science (WoS) research tool, originally known through ISI and currently maintained by Clarivate Analytics, was used for conducting the literature review. After a few exploratory searches, it was discovered that the best

PICBE |

506 way to increase the relevant number of articles was to exclude the abstract and limit the search to title only, while increasing the number of keywords, and expanding the returned results through the use of wildcards and the Boolean operator "OR". The final search query is available in Eq 1, and specifies that keywords related to Industry 4.0 and digitalization must be present in the title at the same time with keywords related to entrepreneurship and enterprises.

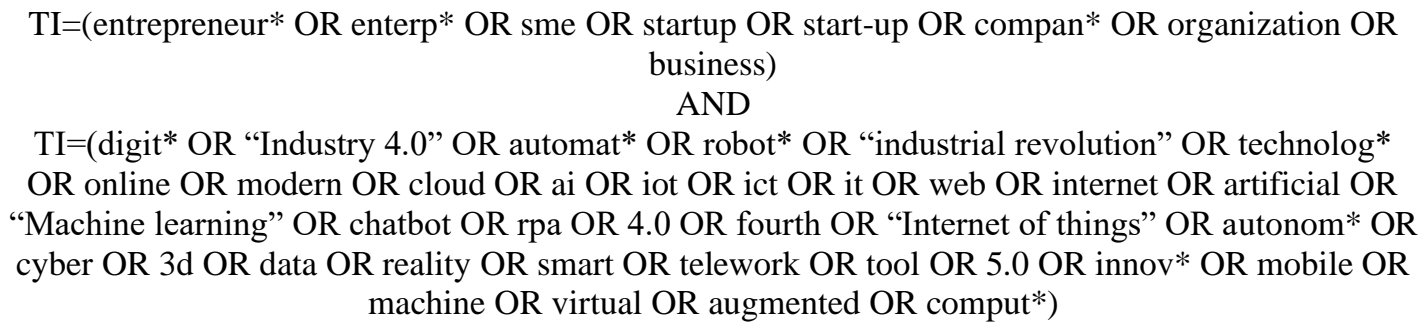

The search is automatically performed for similar words, such as the British English version "organisation" for the American English search term "organization". The results were limited to articles and proceedings papers published in the 2016-2020 period. In order to encompass as many articles studying Romanian entrepreneurship as possible, Romania was chosen as the affiliation country of at least one author. This demarcated 354 papers, which, after manual filtering, were reduced to a final set of 78 articles deemed relevant for this literature review. The exclusion criteria were based on the existence of a quantitative or qualitative analysis on Romanian companies and/or Romanian entrepreneurs that is also linked with the concepts of digitalization and Industry 4.0. The same search query was used on the Scopus database, however, most relevant articles were overlapping with the WoS ones, and, among the ones indexed only on the Scopus database, only a few were appropriate and those were not introducing any new topics.

For analysis, co-occurrence networks were built in VOSviewer, as an addition to manual filtering, categorization and synthesis.

\section{Results and discussion}

The final set of 78 articles was split into two categories, as presented in Table 1. The results of their analysis are discussed below.

Table 1. Distribution of articles based on category and year of publication

\begin{tabular}{cccccccc}
\hline No. & Category & $\mathbf{2 0 1 6}$ & $\mathbf{2 0 1 7}$ & $\mathbf{2 0 1 8}$ & $\mathbf{2 0 1 9}$ & $\mathbf{2 0 2 0}$ & Total \\
\hline 1. & Technology* & 5 & 5 & 10 & 19 & 10 & 49 \\
2. & Education** & 2 & 6 & 7 & 11 & 3 & 29 \\
\hline
\end{tabular}

* technology related articles that meet the requirements presented in the Methodology

** the use of technology in entrepreneurship education, and the educational needs for technology entrepreneurship Source: authors' research. 


\section{Technology}

During review it was observed that a number of articles are aiming to provide guidance by developing frameworks regarding the particularities of developing and/or implementing different technologies. These articles were not included in the final set of 78 articles considered in this paper, since they are constructed on a purely theoretical and/or engineering approach, without qualitative on quantitative studies on Romanian companies. However, they might be valuable for companies and further reviews with other types of objectives, since they investigated concepts of interest, such as virtual enterprises based on intelligent agents, smart farming, appraising data assets, big data necessities, digitalization impact on leadership concepts, the Huffman code use in management, machine learning for advanced technology companies and decision making, artificial intelligence integration in knowledge creation, augmented reality use in production lines, as well as different devices used in manufacturing.

Figure 1 shows the main themes of the 49 articles that made the cut for the Technology category. The co-occurrence network was constructed in VOSviewer through text mining of their titles and abstracts. The relatedness of items is based on the number of documents they occurred together.

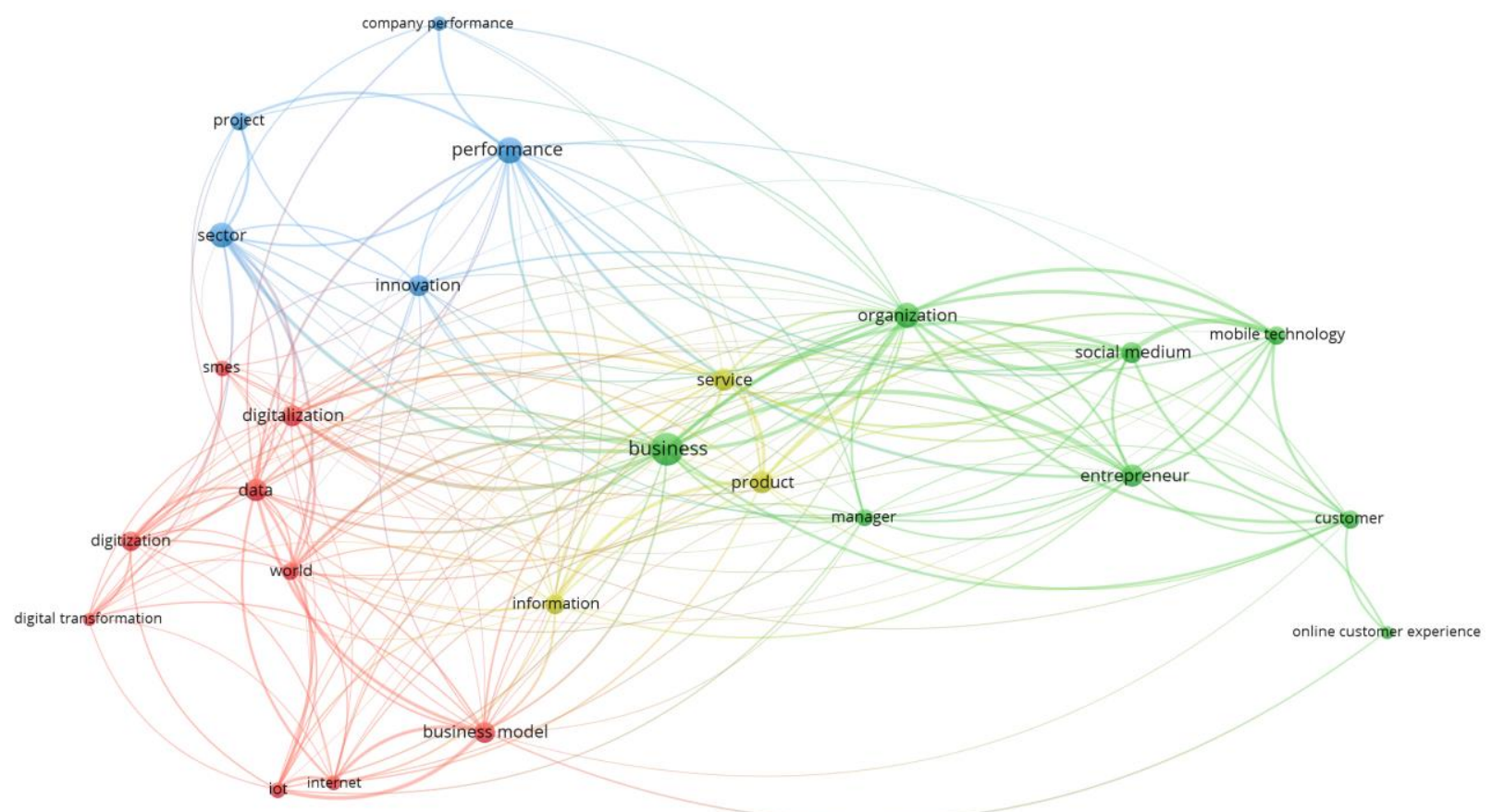

Figure 1. Themes within the Technology category articles

Source: VOSviewer co-occurrence network based on the 49 Technology category articles.

The articles were concerned with (1) innovation and performance, (2) digitization and digital transformation, (3) the link between services, products and information, and (4) the online presence of companies, as represented through the clusters in Figure 1. The themes can be further divided into topics, which are presented in Table 2. The distribution based on topic is the result of manual review and categorization of their contents, and thus, the topic names might not be present verbatim within all papers. The main ideas behind each topic are discussed below. 
Table 2. Distribution of the Technology category articles based on topic

\begin{tabular}{clcc}
\hline No. & & Topic & Articles \\
\hline 1. & IT companies and technology parks & 13 \\
2. & Industry 4.0 in manufacturing & 3 \\
3. & Web presence, marketing and the brand & 15 \\
4. & Digitization and digital transformation & 12 \\
5. & Cyber security & 3 \\
6. & Sustainability & 3 \\
\hline
\end{tabular}

IT companies and technology parks

The Bucharest-Ilfov, North-West, West and Center regions of Romania received EU grants between 2007-2013 for the creation of innovative startups and spin-offs in the priority sectors (i.e. Electronics, Automation and Information Technology) (Cioc, \& Ursacescu, 2017). The Information and Communications Technology (ICT) sector is one of the most productive and fastest growing sectors of the Romanian economy, however, oftentimes some project management and organizational management methods and techniques are misapplied or ignored, leading to significant inefficiencies (Ogrezeanu, \& Scarlat, 2019).

The profitability of Information Technology (IT) companies is impacted by the efficiency of asset use for revenue generation, asset financing source, sales volume growth, and their capacity to generate net income (Ignat, \& Feleaga, 2019). Their performance is strongly linked with their knowledge acquisition and strategic agility (Lungu, 2020). Risk management effectiveness for IT projects depends on the influence of risks on the IT projects, the efficiency of the IT project processes, and the human factor involved with the project (Didiraga et al., 2019). Team management influences the success of market integration when working on an innovative IT startup idea (Dovleac et al., 2016), while concomitant employment may be either a source of resources or a hindrance to entrepreneurship derived from turning a technical innovation in a marketable product or service (Pantea, 2018).

Scientific and technological parks contribute to the economic development of regions, the Liberty Technology Park in Cluj Napoca being an example of successful entrepreneurship, however, the local university is unable to cover the demand for young IT specialists (Gheorghiu. \& Treapat, 2017). Another example of a successful Romanian technology park is the Sema Park in Bucharest (Gheorghiu, 2016).

\section{Industry 4.0 in manufacturing}

The ability to adapt to the rapid developments in Industry 4.0 technologies has become a factor in attaining competitive advantage in most economic sectors (Alexa, \& Alam, 2019). However, there is a lack of information on the steps a small or medium-sized enterprise (SME) production unit should take in order to orient its strategy towards Industry 4.0 (Moica et al., 2018). Assuming the Industry 4.0 concept, Romanian manufacturing managers should strive to achieve lean operations, selecting appropriate ways to attain continuous business development, while also looking into networking opportunities which allow for knowledge creation and sharing (Marin, Tănase et al., 2018).

Web presence, marketing and the brand

Gathering customer information through the company website, social media and other communication mediums is fundamental in the development of strong marketing strategies. 
Companies are mostly using Facebook, however, newer technologies such as wearables are rarely used for customer data gathering in the development of marketing strategies (Maiorescu et al., 2020). For companies doing business on-site, the use of social media marketing through mobile applications (especially Facebook) proved to be effective in targeting audience based on location (Ioanid et al., 2016).

Online customer experience has a role in the development of online marketing campaigns, on designing innovative business models based on customer generated content, and achieving competitive advantage (Micu et al., 2019, Anagnoste et al., 2020, Fedorko et al., 2018). Still, while many companies focus on Facebook for marketing and communication, LinkedIn has a positive influence in increasing innovation potential (Barbu, \& Militaru, 2018). Networking platforms for e-commerce entrepreneurs can also be a good source for increasing know-how and developing new business partnerships, however, they should guarantee privacy, security and a good collaborative environment for sharing information (Neghină et al., 2019).

An analysis of the top ten Romanian organizations in terms of brand value showed that investments in paid search are a significant factor in raising brand awareness through the online environment, while the most important "business card" to invest in is a company website (Niculescu et al., 2019). For instance, large software and IT companies are building their corporate brand identities through their websites by focusing on both internal (i.e. employees and future employees) and external (i.e. the brand promise to their customers) perspectives (Tokes, 2019). Moreover, it was demonstrated that one of the factors contributing to enterprise failure is the quality of organizational online reputation (Oncioiu et al., 2020).

\section{Digitization and digital transformation}

There is a growing pressure over CEE countries to consider investments in advanced technologies, Romania showing a higher interest in big data analytics, compared to Hungary, Slovakia and Serbia (Szabo et al., 2020). However, Romania is among the countries with lower level of digital technology integration compared to the rest of the European Union (EU) (Șchiopu, 2020). For instance, Iceland has made the strongest progress in regards to cloud computing usage, and, at EU level, a strong connection was found between the use of cloud computing services and enterprise level innovation (Mirică et al., 2019). For Romania, cloud computing adoption within SMEs is mostly linked to perceived costs and managers' know-how (Dincă et al., 2019). When it comes to investments in research and development (R\&D) and IT, multinationals in Romania are aligned with the global trends, while Romanian companies are not using collaborative platforms and local hubs for the development of new products, ideas and business models (Pînzaru et al., 2017). However, Romanian businesses have a positive perception regarding digitization, by using mobile devices, authentication systems and specialized software, and believing the quality of risk management could be improved by digital transformation, as long as the technologies are kept upto-date (Prioteasa et al., 2018).

\section{Cyber security}

The increased complexity of cyber threats urges companies to look for solutions from outside and collaborate. For instance, industry-university cooperation in IT and security increases company competitiveness, the partnership between three industrial SMEs and two universities with technical programs providing helpful insights on validating academic research on one side, and knowledge transfer from academia to industry, on the other side (Ichim \& Popescu, 2018). 
Moreover, the COVID-19 pandemic substantially increased the number of employees working from home, challenging the security systems and forcing companies to revise their ICT security policies (Meghișan-Toma \& Nicula, 2020).

\section{Sustainability}

There is a strong need for linking sustainability initiatives with green IT solutions, however, in the case of enterprise resource planning (ERP) system implementations, companies in Romania are mostly focused on the operational benefits, and less on the sustainability ones (Ursăcescu et al., 2019). Moreover, compared to the EU average, Romanian SMEs are less likely to embrace measures for improving their resource efficiency, and thus, the development of eco-industrial parks seeking economic and environmental performance has a strategic role in the green development of SMEs at local and regional scale (Frone \& Frone, 2018). Nevertheless, some integrations of technology with sustainability initiatives have been made. For instance, the first implementation of green wastewater treatment technology in Romanian agritourism facilities resulted in good contaminant removal rates as well as the preservation of landscape beauty (Paruch et al., 2019).

\section{Education}

Figure 2 shows the main themes of the 29 articles that made the cut for the Education category. A co-occurrence network was constructed in the same manner as for Figure 1.

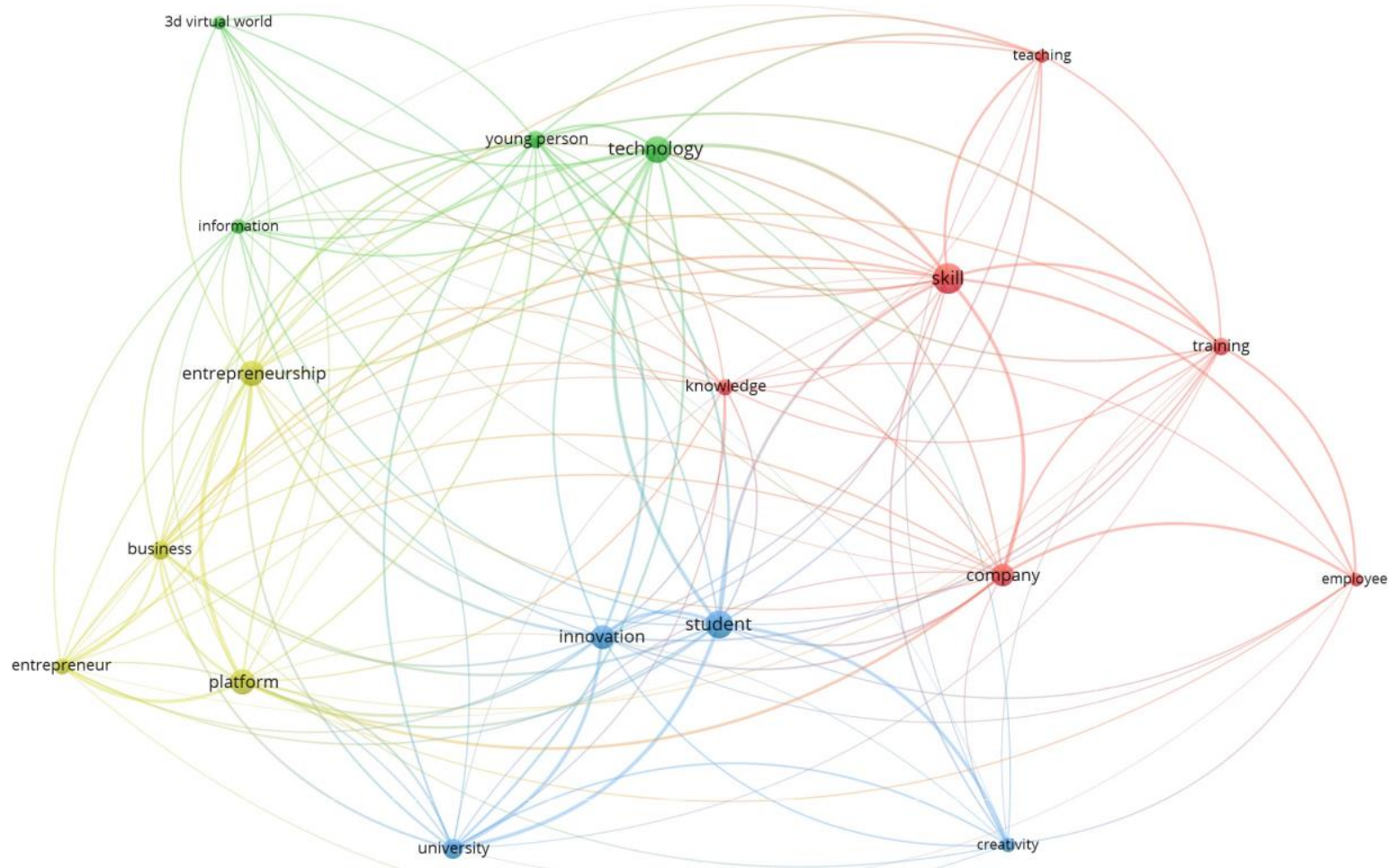

Figure 2. Themes within the Education category articles

Source: VOSviewer co-occurrence network based on the 29 Education category articles.

DOI: 10.2478/picbe-2021-0046, pp. 505-517, ISSN 2558-9652 |

Proceedings of the $15^{\text {th }}$ International Conference on Business Excellence 2021 
The articles were concerned with (1) e-learning and collaborative platforms for entrepreneurs, (2) university studies, creativity and innovation, (3) company trainings for increasing technology skills, and (4) virtual reality platforms for entrepreneurship education, as represented through the clusters in Figure 2. After manual review and categorization, the themes can be seen from two main directions, as available in Table 3 and presented below.

Table 3. Main directions of the Education category articles

\begin{tabular}{ccc}
\hline No. & \multicolumn{1}{c}{ Topic } & Articles \\
\hline 1. & e-Learning platforms and the use of technology in entrepreneurship education & 13 \\
2. & Technology transfer and educational needs of technology entrepreneurship & 16 \\
\hline & & Source: authors' research
\end{tabular}

e-Learning platforms and the use of technology in entrepreneurship education

A number of e-learning platform projects financed by the European Commission with the aim of increasing entrepreneurship knowledge have been documented through academic papers. Youth entrepreneurship is a priority on the EU policy agenda and is considered vital for creating sustainable growth, innovation and combating unemployment (Palkova et al., 2016). For example, a project for increasing entrepreneurship skills for the ICT and STEM domains (i.e. Science, Technology, Engineering and Mathematics) was developed as a virtual reality (VR) educational environment, and is expected to create more attractive ways of teaching (Palkova et al., 2016, de Mattos, \& Popovici, 2018). Other such projects are: a start-up simulation platform for innovation and entrepreneurship in the Life Sciences field (Toma et al., 2020), a social game built as a 3D virtual world for teaching entrepreneurship to young business practitioners (Ionitescu et al., 2019a), software for innovation training and decision making within textiles enterprises (Blaga et al., 2017), an interactive platform for entrepreneurship education in the additive manufacturing area (Ulmeanu et al., 2019), and a VR educational platform for teaching agriculture entrepreneurship, expected to increase young students' motivation, as they are also using this technology for entertainment (Ionitescu et al., 2019b).

Targeting the young entrepreneurs' learning needs through massive open online courses might also come as a great advantage in supporting the Smart cities and specialization policies (Holotescu et al., 2017). Moreover, creating e-learning platforms for product innovation and entrepreneurship education for engineering students could increase student collaboration and provide the opportunity for gaining financial support, creating spin-offs and developing technology entrepreneurship (Alexe, \& Alexe, 2019). The long term positive evolution of companies can be sustained by designing innovative e-learning platforms and national communication strategies (Maerean, \& Albu, 2019), while their number can be increased through gamified platforms for entrepreneurship (Rughinis et al., 2016).

\section{Technology transfer and educational needs of technology entrepreneurship}

Even if some native abilities are needed for increasing the chances of entrepreneurial success (Radu et al., 2018), Romania manifests inefficiencies in entrepreneurship education, including technology entrepreneurship, requiring innovative and interactive approaches (Furdui et al., 2019). Education institutions should implement online teaching methods, not forgetting that they cover more than online content delivery (Marin, Boanță et al., 2018). The future of e-learning could mean the simulation of different scenarios through VR, placing students in situations that may or may not be possible to create in the real world (Bucea-Manea-Tonis et al., 2018). Moreover, developing the 
population's ICT skills could decrease social exclusion and increase the level of employment (Avram et al., 2019), while also bringing value to companies and entrepreneurship, as high levels of IT skills increase customer co-creation value (Barbu, \& Militaru, 2019).

Regarding technology transfer between the productive sector and research organizations, it was discovered that it is enabled by: (1) financing, (2) the process' environment, and (3) its synergy effect, while also being constrained by: (1) financing complexity, (2) improper focus, and (3) the required level of knowledge on the topic (Ștefan et al., 2020).

PICBE |

512

\section{Conclusion}

As a result of manual filtering, categorization and synthesis of the relevant articles found through Eq.1, as well as co-occurrence networks built in VOSviewer, the main directions of the studies characterizing Romanian companies within the digitalization and Industry 4.0 context were discovered to be in six areas on the use of technology in business (i.e. IT companies and technology parks; Industry 4.0 in manufacturing; Web presence, marketing and the brand; Digitization and digital transformation; Cyber security; and Sustainability) and two areas which are also related to education (i.e. e-Learning platforms and the use of technology in entrepreneurship education; and Technology transfer and educational needs of technology entrepreneurship).

The ICT sector is one of the most productive and fastest growing sectors of the Romanian economy. However, Romania lacks a national digital transformation strategy aimed at supporting the digitalization of enterprises, and is manifesting inefficiencies in entrepreneurship education, including technology entrepreneurship, requiring new approaches, such as: e-learning and VR platforms for product innovation and entrepreneurship education for students, the population, and entrepreneurs.

SMEs are affected by the lack of information on the steps they should take in order to orient their strategy towards Industry 4.0. Thus, collaboration's importance was emphasized in a number of studies, Romanian managers and entrepreneurs being advised to look into networking opportunities through collaborative platforms and local hubs. Moreover, industry-university technology transfer and collaborative research can be valuable both ways (Dima et al., 2017), while scientific and technological parks contribute to the economic development of regions.

The research is limited by being based only on relevant articles and conference proceedings published within last five years in WoS. Further research can either expand the search, or pinpoint one of the themes or issues in this study and capture it in more detail.

\section{References}

Alexa, L., \& Alam, M. (2019). Industry 4.0 Adoption. An Overview of European Union Enterprises. In Soliman, K. (Ed.) VISION 2025: Education Excellence and Management Of Innovations Through Sustainable Economic Competitive Advantage. $34^{\text {th }}$ IBIMA Conference. Retrieved: https://ibima.org/accepted-paper/industry-4-0-adoption-an-over view-of-european-union-enterprises/.

Alexe, C., \& Alexe, C. (2019). E-Learning - Facilitator Tool for the Development of Technological Entrepreneurship. Conference proceedings of "eLearning and Software for Education" (eLSE), 15(2). Retrieved: https://www.ceeol.com/search/article-detail?id=782686.

Anagnoste, S., Biclesanu, I., Chailan, C., \& Negoiasa, B. (2020). Effective Web Presence Solutions for Enhancing e-Fashion Customers' Satisfaction. Innovative Models to Revive the Global 
Economy. Proceedings of the International Conference on Economics and Social Sciences. Sciendo. https://doi.org/10.2478/9788395815072-039.

Anagnoste, S., Biclesanu, I., D’Ascenzo, F., \& Savastano, M. (2021). The Role of Chatbots in EndTo-End Intelligent Automation and Future Employment Dynamics. Business Revolution in a Digital Era. Springer Proceedings in Business and Economics. Springer, Cham. https://doi.org/10.1007/978-3-030-59972-0_20.

Avram, A., Benvenuto, M., Avram, C. D., \& Gravili, G. (2019). Assuring SME's Sustainable PICBE | Competitiveness in the Digital Era: A Labor Policy between Guaranteed Minimum Wage and ICT Skill Mismatch. Sustainability, 11(10). http://dx.doi.org/10.3390/su11102918.

Barbu, A., \& Militaru, G. (2018). Investigating the innovation potential of a company obtained through social media. Proceedings of the 12th International Management Conference: Management Perspectives in the Digital Era (IMC 2018), 12(1). Retrieved: http://confe rinta.management.ase.ro/archives/2018/pdf/2_6.pdf.

Barbu, A., \& Militaru, G. (2019). Value Co-Creation between Manufacturing Companies and Customers. The Role of Information Technology Competency. Procedia Manufacturing 32. DOI: 10.1016/j.promfg.2019.02.323.

Blaga, M., Harpa, R., Radulescu, I., \& Stepjanovic, Z. (2017). E-learning for textile enterprises innovation improvement. IOP Conference Series Materials Science and Engineering 254(22):222001. DOI: 10.1088/1757-899X/254/22/222001.

Bleicher, J. \& Stanley, H. (2018). Digitization as a catalyst for business model innovation a threestep approach in facilitating economic success. Journal of Business Management, 4(2). Retrieved: http://www.theaspd.com/resources/jbm\%20vol.\%204-2-1.pdf.

Bucea-Manea-Tonis, R., Pistol, L., \& Bucea-Manea-Tonis, R. (2018). Model of innovation and creativity in the exchange between universities and business field. ADLRO. https://doi.org/10.12753/2066-026X-18-231.

Chiriseala, A., (2021). Romania's Tech Angels members invest EUR 4 mln in 75 startups. Romaniainsider.com. Retrieved January 2021 from: https://www.romania-insider.com/tech-angels75-startups-invest-jan-2021.

Cioc, M., \& Ursacescu, M. (2017). Innovative Entrepreneurship In A Regional Perspective: An Empirical Research On Romanian Start-Ups. Proceedings Of The 11th International Management Conference: The Role Of Management In The Economic Paradigm Of The Xxist Century (IMC 2017), 11(1). Retrieved: https://ideas.repec.org/a/rom/mancon/ v11y2017i1p871-877.html.

de Mattos, D., \& Popovici, D. (2018). VR4STEM-A 3D Virtual World for Assisting Young People to Gain Entrepreneurship Skill in the STEM and ICT Domains. 12th International Technology, Education and Development Conference (INTED Proceedings). Retrieved: https://library.iated.org/view/PAULODEMATTOS2018VR4.

Didiraga, O., Brândaș, V., Batagan, L., \& Alecu, F. (2019). Characteristics of Effective IT Project Risk Management in Romanian IT Companies. Economic Computation and Economic Cybernetics Studies and Research 53(4). 10.24818/18423264/53.4.19.11.

Dima, A., Hadad, S., \& Luchian, I. (2017). Review on the dimensions of business-university alliances. Proceedings of the International Conference on Business Excellence, 11(1). DOI: 10.1515/picbe-2017-0007.

Dincă, V., Dima, A., \& Rozsa, Z. (2019). Determinants of cloud computing adoption by Romanian SMEs in the digital economy. Journal of Business Economics and Management, 20(4). https://doi.org/10.3846/jbem.2019.9856. 
Dovleac, R., Ionica, A., \& Leba, M. (2016). A New Approach on IT Startups Project Management. Review of Management and Economic Engineering International Management Conference, 16(4). WOSUID: WOS:000385997200004.

European Commission (2020). Digital Economy and Society Index | Romania. European Commission. Retrieved: https://ec.europa.eu/newsroom/dae/document.cfm?doc_id=66928

Fedorko, I., Bacik, R., \& Gavurova, B. (2018). Technology acceptance model in e-commerce segment. Management \& Marketing. Challenges for the Knowledge Society, 13(4). https://doi.org/10.2478/mmcks-2018-0034.

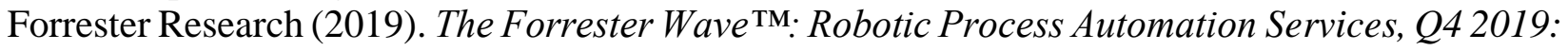
The 13 Providers That Matter Most And How They Stack Up. Forrester. Retrieved January 2021: https://www.forrester.com/report/The+Forrester+Wave+Robotic+Process+Automa tion+Q4+2019/-/E-RES147757.

Frone, D., \& Frone, S. (2018). Eco-innovation parks for a green development in small and medium sized enterprises. Scientific Papers, Series Management, Economic Engineering in Agriculture and rural development, 18(2). Retrieved: http://managementjournal.usamv.ro/ pdf/vol.18_2/Art25.pdf.

Furdui, A., Edelhauser, E., \& Popa, E. (2019). Innovation Management Correlated with the Models of Development of Technological Entrepreneurship. Quality-Access To Success, 10(1). Retrieved: https://search.proquest.com/openview/9d2b54e237a50fac5ecf7c3044183cf7/ 1?pq-origsite $=$ gscholar\&cbl $=1046413$.

Gheorghiu, A. (2016). Technology Entrepreneurship in Romania - A Great Opportunity for the Future Years. 4th International Academic Conference Strategica. Retrieved: https://www.researchgate.net/publication/317185044_Technology_entrepreneurship_in_R omania_-a_great_opportunity_for_the_future_years.

Gheorghiu, A., \& Treapat, L. (2017). Liberty Technology Park Cluj - A Case Study of Successful Entrepreneurship. 5th International Academic Conference on Strategica - Shift! Major Challenges of Today's Economy. Retrieved: https://www.researchgate.net/publication/ 320225776_Strategica_Shift_Major_Challenges_of_Today's_Economy.

Grigorescu, A., Zamfir, A., \& Mocanu, C. (2020). Emerging trends and drivers for knowledgeintensive economy. Management \& Marketing. Challenges for the Knowledge Society, 15(2). https://doi.org/10.2478/mmcks-2020-0011.

Holotescu, C., Gotiu, L., Andone, D., Cismariu, L., Grosseck, G., \& Slavici, T. (2017). Entrepreneurship Learning Ecosystem for Smart Cities through MOOCs. Brain-Broad Research in Artificial Intelligence and Neuroscience, 8(2). Retrieved: https://doaj.org/article/1f76f2b025e144b0bba213bdc3daa75c?.

Ichim, L., \& Popescu, D. (2018). Flexible university-industry cooperation in Romanian program innovation checks as support for increasing SME competitiveness. EDULEARN18 Proceedings. DOI: 10.21125/edulearn.2018.0163.

Ignat, I., \& Feleaga, L. (2019). The Role of IT in the Logistics Sector: The Impact of Dupont Model on the Profitability of IT Companies. LOGFORUM, 15(2). DOI: 10.17270/J.LOG.2019.236

Ioanid, A., Scarlat, C., \& Militaru, G. (2016). How Mobile Technologies and Social Media Merge to Help Managers and Entrepreneurs Fast Track Their Business. Proceedings of the 11th European Conference on Innovation and Entrepreneurship. Retrieved: https://search. proquest.com/openview/c90a30745435909fc9dafe1ae803c076/1?pq-origsite=gscholar\& cbl=396494. 
Ionitescu, S., Melo, R., Popovici, D., \& Conci, A. (2019a). Biz4fun - 3d Virtual World As A Motivator For Youth Entrepreneurship Education. Retrieved: http://managementjournal. usamv.ro/pdf/vol.19_4/Art18.pdf.

Ionitescu, S., Melo, R., Popovici, D., \& Conci, A. (2019b). AGRIENT - Using a 3D Virtual World to Enhance Agriculture Entrepreneurship Education. Scientific Papers. Series "Management, Economic Engineering in Agriculture and rural development", 19(4). Retrieved: http://managementjournal.usamv.ro/pdf/vol.19_4/Art17.pdf.

Lanzolla, G., \& Frankort, H. (2016). The Online Shadow of Offline Signals: Which Sellers Get Contacted in B2B marketplace? Academy of Management Journal, 59(1). Retrieved: https://journals.aom.org/doi/full/10.5465/amj.2014.0051.

Lungu, M. (2020). Factors determining company performance in the IT industry, Management \& Marketing. Challenges for the Knowledge Society, 15(1). DOI: https://doi.org/10.2478/ mmcks-2020-0004.

Maerean, C., \& Albu, E. (2019). Befriending Innovation - From Entrepreneurial Vision To Public Policy. Proceedings of the International Management Conference, 13(1). Retrieved: https://ideas.repec.org/a/rom/mancon/v13y2019i1p499-507.html.

Maiorescu, I., Bucur, M., Georgescu, B., Moise, D., Strat, V., \& Zgură, I. (2020). Social Media and IOT Wearables in Developing Marketing Strategies. Do SMEs Differ From Large Enterprises? Sustainability, 12(18). DOI: http://dx.doi.org/10.3390/su12187292.

Marin, A., Boanţă, L., Țelinoiu, A., Darie, G., \& Din, M. (2018). Supporting entrepreneurship and innovation in higher education in Romania, ICERI2018 Proceedings. Retrieved: https://library.iated.org/view/MARIN2018SUP.

Marin, A., Tanase, N., Guda, M., Boanta, L., \& Purcarea, A. (2018). Agile Innovation and Business Model Agility within Enterprise Systems. 6th Review of Management and Economic Engineering International Management Conference. Retrieved: http://www.aos.ro/wpcontent/proceedings/PVol10Nr1Art.5.pdf.

Meghișan-Toma, G., \& Nicula, V. (2020). ICT Security Measures for the Companies within European Union Member States - Perspectives in COVID-19 Context. Proceedings of the International Conference on Business Excellence, 14(1). DOI: https://doi.org/10.2478/ picbe-2020-0035.

Micu, A., Bouzaabia, O., Bouzaabia, R., Micu, A., \& Capatina, A. (2019). Online customer experience in e-retailing: implications for web entrepreneurship. International Entrepreneurship and Management Journal, 15. https://doi.org/10.1007/s11365-01900564-x.

Mirică, A., Pană, A., Glăvan, I., Ferariu, G., Chiper, I., Cîrnu V., \& Velișcă, N. (2019). Innovation in European Enterprises: Does Cloud Computing Count? 33rd IBIMA Conference Proceedings. Retrieved: https://ibima.org/accepted-paper/innovation-in-european-enter prises-does-cloud-computing-count/.

Moica, S., Ganzarain, J., Ibarra, D., \& Ferencz, P. (2018). Change Made in Shop Floor Management to Transform a Conventional Production System into an Industry 4.0 Case studies in SME automotive production manufacturing. 7th International Conference on Industrial Technology and Management (ICITM 2018). Retrieved: https://www. researchgate.net/publication/323870930_Change_Made_in_Shop_Floor_Management_to _Transform_a_Conventional_Production_System_into_an_Industry_40_Case_studies_in_ SME_automotive_production_manufacturing. 
Neghină, R., Mănescu, V., Ganciu, M., Ilie, D., \& Militaru, G. (2019). Online business networking experience research on ecommerce entrepreneurs. Proceedings of the International Conference on Business Excellence, 13(1). DOI: https://doi.org/10.2478/picbe-2019-0034.

Niculescu, A., Dumitru, D., Purdescu, C., \& Popescu, M. (2019). Enhancing Brand Value of Modern Organizations through Digital Marketing Tools and Techniques : A Study on Top Ten Romanian Companies. TEM Journal, 8(1). DOI: 10.18421/TEM81-24.

Ogrezeanu, A., \& Scarlat, C. (2019). Managerial Challenges and Limitations to Innovation and Growth in Romanian Project Based Companies in the ICT Sector. Quality-Access to Success, 12(3). Retrieved: https://www.srac.ro/calitatea/en/arhiva/supliment/2019/QasContents_Vol.20_S3_October-2019.pdf.

Oncioiu, I., Popescu, D., Anghel, E., Petrescu, A., Bîlcan, F., \& Petrescu, M. (2020). Online Company Reputation - A Thorny Problem for Optimizing Corporate Sustainability. Sustainability, 12(14). MDPI AG. http://dx.doi.org/10.3390/su12145547.

Palkova, Z., Palko, M., Popovici, D., Hatzilygeroudis, I., \& Stoyanov, B. (2016). Virtual Reality for STEM Entrepreneurship Training. ICERI2016 Proceedings: 9th International Conference of Education, Research and Innovation, pp. 6184-6191. Retrieved: https://library.iated.org/view/PALKOVA2016VIR.

Pantea, M. (2018). Employment-to-Entrepreneurship Interface in the Context of Tech Innovation. A Qualitative Analysis in Romania. Journal for East European Management Studies, 23(1). DOI: 10.5771/0949-6181-2018-1-128.

Paruch, A., Mæhlum, T., Eltun, R., Tapu, E., \& Spinu, O. (2019). Green wastewater treatment technology for agritourism business in Romania. Ecological Engineering. 138. 133-137. DOI: 10.1016/j.ecoleng.2019.07.005.

Pînzaru, F., Anghel, L., \& Mihalcea, A. (2017). Sustainable Management in the New Economy: Are Romanian Companies Ready for the Digital Challenge? In Zanele, $N$., \& Thabang, M. (Eds.), IGMLG 2017 - Proceedings of the 5th International Conference on Management, Leadership and Governance, 346-352, Reading, UK. Retrieved: https://www.academicbookshop.com/ourshop/prod_5929634-ICMLG-2017-PDF-Proceedings-of-the-5thInternational-Conference-on-Management-Leadership-and-Governance.html.

Prioteasa, A., Chicu, N., \& Ciocoiu, C. (2018). Implications of Digitization on Risk Management in Romanian Companies. $31^{s t}$ IBIMA Conference. Retrieved: https://ibima.org/acceptedpaper/implications-of-digitization-on-risk-management-in-romanian-companies/.

Radu, N., Chirvase, A., Babeanu, N., Popa, O., Hastaran, F., Velykiene, B., \& Begea, M. (2018). Education management in the field of life sciences-skills needed to start and develop an innovative SME. Scientific Papers Series Management, Economic Engineering in Agriculture and Rural Development, 18(2). Retrieved: https://www.researchgate.net/ publication/327971982_education_management_in_the_field_of_life_sciences-skills_ needed_to_start_and_develop_an_innovative_sme.

Rughinis, R., Rosner, D., \& Matei, Ș. (2016). What is it like to be an entrepreneur? A framework for analysing multivoicedness of meaning in gamified learning platforms. Conference proceedings of "eLearning and Software for Education" (eLSE), 1. Retrieved: https://www.ceeol.com/search/article-detail?id=522409.

Şchiopu, R. (2020). Business Digitization in the European Union, Proceedings of the International Conference on Business Excellence, 14(1), 385-397, DOI: https://doi.org/10.2478/picbe2020-0037. 
Schwab, K. (2015). The Fourth Industrial Revolution. Foreign Affairs. Retrieved January 2020 from: https://www.foreignaffairs.com/articles/2015-12-12/fourth-industrial-revolution.

Schwab, K. (2016). The Fourth Industrial Revolution: what it means, how to respond. World Economic Forum. Retrieved January 2020 from: https://www.weforum.org/agenda/ 2016/01/the-fourth-industrial-revolution-what-it-means-and-how-to-respond/.

Ștefan, S., Simion, C., Popa, Ș., \& Potcovaru, A. (2020). Enablers and Barriers of Technology Transfer in Romanian Organizations in the Context of the Knowledge-Based Economy: A Factor Analysis. Management Research \& Practice. 12(4), Retrieved: http://mrp.ase.ro/ no124/f4.pdf.

Szabo, R., Vuksanović Herceg, I., Hanák, R., Hortovanyi, L., Romanová, A., Mocan, M., \& Djuričin, D. (2020). Industry 4.0 Implementation in B2B Companies: Cross-Country Empirical Evidence on Digital Transformation in the CEE Region. Sustainability, 12(22), 9538. MDPI AG, http://dx.doi.org/10.3390/su12229538.

Tokes, G. (2019). The Brand Identity of Cluj-Napoca Software and IT Companies from the Perspective of the Analysis of Their Websites. Communication: Strategic Perspectives. Retrieved: https://www.academia.edu/38666829/News_Sharing_on_Social_Media_Plat forms_Theoretical_Approaches.

Toma, R., Margarit, G., Garais, G., \& Matei, F. (2020). E-Learning Platform for Start-Up Simulation in Life Science and Business Field - A Useful Educational Tool. Scientific Papers. Series "Management, Economic Engineering In Agriculture And Rural Development", 20(2), Retrieved: http://managementjournal.usamv.ro/pdf/vol.20_2/Art66 .pdf.

Ulmeanu, M., Doicin, C., Roșca, L., Rennie, A., Abram, T., \& Bajdor, P. (2019). TecHUB 4.0 Technology and Entrepreneurship Education for Bridging the Gap in Smart Product Development. MATEC Web Conf, https://doi.org/10.1051/matecconf/201929013012.

Ursăcescu, M., Popescu, D., State, C., \& Smeureanu, I. (2019). Assessing the Greenness of Enterprise Resource Planning Systems through Green IT Solutions: A Romanian Perspective. Sustainability, 11(16), 4472, MDPI AG, http://dx.doi.org/10.3390/su11164 472. 